Modelling the comparative costs of Namaste Care: Results from the Namaste Care Intervention UK study

\begin{tabular}{|r|l|}
\hline Journal: & Working with Older People \\
\hline Manuscript ID & WWOP-11-2020-0056 \\
\hline Manuscript Type: & Research Paper \\
\hline Keywords: & $\begin{array}{l}\text { Namaste Care, advanced dementia, cost model, care homes, dementia, } \\
\text { older people }\end{array}$ \\
\hline \multicolumn{2}{|l}{} \\
\hline
\end{tabular}

SCHOLARONE ${ }^{\text {m }}$

Manuscripts 


\title{
Modelling the comparative costs of Namaste Care: Results from the Namaste Care Intervention UK study
}

\begin{abstract}
Purpose: To populate a theoretical cost model with real-world data, calculating staffing, resource and consumable costs of delivering NCI-UK sessions versus 'usual care' for care home residents with advanced dementia.
\end{abstract}

Design: Data from five care homes delivering $\mathrm{NCl}-\mathrm{UK}$ sessions populated the cost model to generate session- and resident-level costs. Comparator usual care costs were calculated based on expert opinion and observational data. Outcome data for residents assessed the impact of $\mathrm{NCl}-\mathrm{UK}$ sessions and aligned with the resident-level costs of $\mathrm{NCl}-\mathrm{UK}$.

Findings: $\mathrm{NCl}-\mathrm{UK}$ had a positive impact on residents' physical, social and emotional wellbeing. An average $\mathrm{NCl}-U K$ group session cost $£ 220.53,22 \%$ more than usual care, and ran for 1.5-2 hours per day for 4-9 residents. No additional staff were employed to deliver $\mathrm{NCl}$ UK, but staff-resident ratios were higher during Namaste Care. Usual care costs were calculated for the same time period when no group activity was organised. The average cost per resident, per $\mathrm{NCl}$-UK session was $£ 38.01, £ 7.24$ more than usual care. In reality, costs were offset by consumables and resources being available from stock within a home.

Originality: Activity costs are rarely calculated as the focus tends to be on impact and outcomes. This article shows that, although not cost neutral as previously thought, NCI-UK is a low-cost way of improving the lives of people living with advanced dementia in care homes.

\section{Introduction}

Namaste Care is a non-pharmacological, multi-component intervention designed to improve care for people living with advanced dementia in care homes. Using daily sessions delivered by care staff, Namaste Care brings together small groups of residents with significant cognitive disabilities and provides sensory stimulation, emotional connection and physical 
comfort. Developed in the USA (Simard, 2013), it has been shown to reduce distress behaviours, depressive symptoms, pain, use of antipsychotic medications and inappropriate hospitalisation in people living with advanced dementia in care homes (Stacpoole and Thompson, 2014). The Namaste Care Intervention UK (NCl-UK) is a refined and standardised version of the original intervention. It incorporates evidence from both research and practice and has been previously described by Bray et al. (2019a) and Latham et al. (2020).

As part of a three-year research project exploring the barriers and facilitators to the implementation of $\mathrm{NCl}-\mathrm{UK}$ within care homes, a cost model was previously developed to investigate the full cost of delivering a NCI-UK session (Bray et al., 2019b). To reflect the full economic cost of $\mathrm{NCl}-\mathrm{UK}$, all resources expended during a session are included in the $\mathrm{NCl}-$ UK cost model. This includes staff time and consumable items such as furniture, pillows and music. The NCl-UK cost model makes it possible to estimate costs in terms of staff, capital and consumable requirements, and provides a cost per session or per resident, taking into account the components delivered within an individual session, such as food treats, music, and hand massage.

Namaste Care is said to be cost neutral as it does not require expensive equipment or additional staff and space (Stacpoole and Thompsell, 2014). However, little is known about the changes needed within a care home to implement Namaste Care, such as resource use, planning time and session costs. In addition to providing important information about the costs of individual sessions, the $\mathrm{NCl}-\mathrm{UK}$ cost model enables the wider project to examine the costs and benefits of delivering $\mathrm{NCl}-\mathrm{UK}$. The flexibility of the cost model makes it possible to generate costs for comparable 'usual care', which represents the care residents with advanced dementia would receive on a day-to-day basis if they were not participating in a NCl-UK session. By comparing NCI-UK and usual care costs, the relative or 'incremental' cost of delivering $\mathrm{NCl}-\mathrm{UK}$ enables the affordability of $\mathrm{NCl}-\mathrm{UK}$ to be assessed. When 
combined with outcome measures capturing the impact of $\mathrm{NCl}-\mathrm{UK}$ sessions, cost information can be used to determine the potential cost-benefit of $\mathrm{NCl}-\mathrm{UK}$.

$\mathrm{NCl}-\mathrm{UK}$ was implemented in five care homes over a 3-6 month period. For each $\mathrm{NCl}-\mathrm{UK}$ session delivered, care home staff used the 'Namaste Short Questionnaire' (NSQ) to record standard information relating to duration, attendees, and components delivered. The NSQ was developed specifically for the research, and also captures staff-rated session data for each resident who consented to be part of the research. Staff used a five-point scale to rate the physical wellbeing, emotional wellbeing and awareness/alertness of residents before and after each $\mathrm{NCl}-\mathrm{UK}$ session. An increase on the scale reflects a positive impact on the residents. The process for obtaining consent from participants was approved by the Health Research Authority (South Central-Oxford C Research Ethics Committee; Reference 17/SC/0430).

This article shows how the theoretical $\mathrm{NCl}-\mathrm{UK}$ cost model can be populated with real-world NSQ data to calculate the relative costs of delivering $\mathrm{NCl}$-UK sessions compared to 'usual care' for care home residents with advanced dementia. It also provides information regarding resource use and planning time required to implement NCI-UK. For the purpose of the research, $\mathrm{NCl}-\mathrm{UK}$ is considered to be an intervention that does not require a resident or their family to spend anything in order to participate. Therefore, the cost of delivering NCI-UK focuses on the care home perspective, not the cost to residents or families.

\section{Methods}

Descriptive analysis of the $\mathrm{NCl}-\mathrm{UK}$ sessions was carried out on the full data set, with cases of missing data being resolved by substituting the most frequently occurring values from similar sessions. The only exception related to the number of relatives and staff present during a session. If relatives were known to be present but the number was not specified, it was assumed that there was one relative and all other people were staff. 
The complete data set was used to populate the cost model and generate session costs and costs per resident, per session. Comparator costs for usual care were generated using the approach defined in Bray et al. (2019b), which combined expert opinion and researcher observations from the wider research project.

Change in NSQ outcomes for each resident in each NCI-UK session were calculated to enable the cost per resident to be aligned with the impact. In-depth observations using PIECE-dem (Brooker et al., 2013) were conducted on a subset of residents during NCI-UK sessions and during periods of usual care. This observational data was used as a basis from which to extrapolate likely NSQ outcomes for residents during usual care. As a form of sensitivity analysis, three scenarios were considered for usual care:

1. Residents improved as a result of usual care

2. Residents remained at the same level as a result of usual care

3. Residents declined as a result of usual care

The incremental cost-effectiveness ratio (ICER) was applied to the overall NSQ scores for each of the three scenarios to find the average incremental cost associated with a change of one point on the NSQ scale. The ICER formula used was:

\section{Cost of NCl-UK - Cost of usual care}

Change in NCI-UK NSQ score - Change in usual care NSQ score

\section{Results}

Overview of NCI-UK sessions delivered

Implementation of $\mathrm{NCl}-U K$ varied between the care homes (Table I). On average, Azalea Court delivered the shortest sessions, with Gardenia Lodge running the longest ones. Clover House had the biggest resident group sizes with Gardenia Lodge having the smallest. Clover House only had one member of staff running a session regardless of group size, whereas 
sessions at Gardenia Lodge were more likely to be run by a pair of staff. Time spent planning $\mathrm{NCl}-\mathrm{UK}$ sessions was ongoing, resulting in Azalea Court and Elm Gardens having the larger totals as they implemented $\mathrm{NCl}-\mathrm{UK}$ sessions for longer.

---Insert Table I here---

The total cost per care home of delivering all of the $\mathrm{NCI}-U K$ sessions is provided in Table II, together with comparative costs for usual care. The context for these costs is provided by the number of $\mathrm{NCl}$-UK sessions delivered in each care home and the total number of residents taking part in the sessions.

---Insert Table II here---

Session level costs of delivering NCl-UK

An overview of $\mathrm{NCl}-\mathrm{UK}$ session costs is provided in Figure 1, showing the number of sessions with a cost that falls within each $£ 20$ bracket for each care home and overall. Although the overall range of costs is quite broad at $£ 80-£ 480$, the more expensive sessions are rare occurrences with most sessions costing between $£ 140$ and $£ 260$. For Azalea Court, Elm Gardens and Foxglove Place, most sessions tend to be in this $£ 140-£ 260$ range, while for Clover House and Gardenia Lodge they are more expensive at around $£ 220-£ 360$. This is in part due to Clover House and Gardenia Lodge running fewer sessions and the cost model spreading the cost over the number of sessions delivered.

---Figure 1 to be inserted here---

On average, $\mathrm{NCl}-\mathrm{UK}$ sessions were more expensive than usual care sessions by around $£ 38(22 \%)$ (Table III). When breaking down the costs by resource type it was seen that 
capital costs were the same for $\mathrm{NCl}-\mathrm{UK}$ and usual care; consumable costs were lower for NCI-UK by nearly $£ 10$; and staff costs were higher for NCI-UK by about $£ 48$.

---Insert Table III here---

\section{Resident level costs of delivering $\mathrm{NCI}$-UK}

Overall, 1649 individual 'cases' were included in the analysis for the 48 residents who participated in the research, with a 'case' representing an attendance at a $\mathrm{NCl}-\mathrm{UK}$ session. Table IV shows that delivering NCI-UK cost £38.01 per resident, per session on average, and the total NSQ score improved by an average of 1.31 points. This equates to an improvement of $18.6 \%$ during a $\mathrm{NCI}-\mathrm{UK}$ session. Delivering $\mathrm{NCl}-\mathrm{UK}$ instead of usual care costs an extra £7.24 per resident, per session. Clover House and Foxglove Place delivered comparatively expensive $\mathrm{NCl}-\mathrm{UK}$ sessions, while Gardenia Lodge ran $\mathrm{NCl}-\mathrm{UK}$ sessions that were only an average of $£ 0.45$ per resident more expensive than usual care.

--Insert Table IV here---

The total incremental cost of delivering NCl-UK instead of usual care was $£ 11,943.41$. The ICER formula was applied for the three usual care scenarios:

- In a scenario where resident outcomes improved during usual care sessions the ICER value was $-£ 4.46$. I.e. spending an extra $£ 4.46$ per resident to provide $\mathrm{NCl}$-UK would not offer any comparative benefit in terms of improving NSQ scores.

- In a scenario where usual care sessions had no impact on resident outcomes the ICER value was $£ 5.53$. I.e. it would be possible to improve NSQ scores by 1 point by spending an extra $£ 5.53$ per resident, per session implementing $\mathrm{NCl}$-UK. 
- In a scenario where resident outcomes declined during usual care sessions the ICER value was $£ 1.22$. I.e. it would be possible to improve NSQ scores by 1 point by spending an extra £1.22 per resident, per session implementing $\mathrm{NCl}-\mathrm{UK}$.

In all scenarios $\mathrm{NCl}$-UK costs more than usual care, but in the second and third scenarios this higher cost is associated with an improvement in outcomes as a result of $\mathrm{NCl}-\mathrm{UK}$.

\section{Limitations}

As this research did not involve a control group, the usual care session information is based on expert opinion and observations of participating residents outside of $\mathrm{NCl}-\mathrm{UK}$ sessions. This may have introduced bias. In addition, as the same residents were observed within $\mathrm{NCl}-\mathrm{UK}$ and usual care the authors cannot rule out effects of one type of care transferring to the other. However, using the same information about the number of sessions run, type of room used, session duration and number of residents for the individual care homes and sessions, should ensure that the usual care costs are as comparable as possible.

As discussed previously, remedial procedures were applied to missing data, highlighting a significant limitation of this costing study. NSQ data relied on care home staff completing forms in real time to be processed by the research team later on. Issues with mis-recording or inconsistent recording could not be corrected and may have been exacerbated during remedial processes. For example, one care home reported that the NSQs were not completed for several weeks as the manager was not present to remind staff. This will have resulted in a significantly lower number of $\mathrm{NCI}-\mathrm{UK}$ sessions than actually occurred, and subsequently a much higher per-session cost than in reality.

The primary limitation, previously acknowledged, is the approach taken regarding staff numbers. The level of detail collected on the NSQ forms meant that assumptions were required regarding the additional people present during a $\mathrm{NCl}-\mathrm{UK}$ session, so a consistent 
approach was applied to all NCl-UK sessions. By assuming all extra people were staff, having a maximum of one relative in a session and not accounting for volunteers, NCI-UK costs relating to staff are likely to be higher than the actual costs in practice. This will have been a factor in the main difference between $\mathrm{NCl}-\mathrm{UK}$ and usual care being related to staff costs. This qualification is of particular note given that qualitative data collection for the wider research project indicated that volunteers were often used within $\mathrm{NCl}-\mathrm{UK}$ sessions. These results should therefore be taken as a strong indication of the comparative costs of $\mathrm{NCI}-\mathrm{UK}$ and usual care, rather than an exact representation. However, it is unlikely that $\mathrm{NCI}-\mathrm{UK}$ sessions would be cheaper than usual care, as the number of additional people would still be the same and have an impact on cost, even if staff wages were not a factor.

\section{Discussion}

The theoretical cost model for $\mathrm{NCl}-\mathrm{UK}$ which was developed during an earlier phase of the research project has subsequently been combined with real-world data to generate the relative cost of delivering $\mathrm{NCI}-U K$ sessions based upon national price weights. It found that session delivery varied between care homes, but in total $521 \mathrm{NCI}-U K$ sessions were run with 3349 resident attendances at a total cost of nearly $£ 115,000$. If $\mathrm{NCI}-\mathrm{UK}$ had not been delivered, the comparable cost of usual care was estimated at just over $£ 95,000$. Unsurprisingly, care homes delivering more $\mathrm{NCI}-U K$ sessions spent more money in total, but also reached a greater number of residents. When compared to the total usual care cost of the same sessions, $\mathrm{NCl}-\mathrm{UK}$ was more expensive in each care home.

While $\mathrm{NCI}-U K$ session costs varied, most were in the $£ 140-£ 260$ range with an average cost of $£ 220.53$. For usual care the average session cost was estimated at $£ 182.42$, making $\mathrm{NCl}$ UK $22 \%$ more expensive than usual care. 
To illustrate the difference between $\mathrm{NCl}-U K$ and usual care, two extreme examples of $\mathrm{NCl}-$ UK sessions are presented; one which was very low cost in comparison to usual care, and one which was very high cost.

\section{Low cost example}

A 1-hour NCl-UK session was run by two members of staff for a group of 18 residents.

During that hour music was playing and residents were provided with soft blankets.

Residents were engaged through touch, having a variety of tactile objects and soft toys. The session was relatively quiet with no expensive components being delivered. Consequently, the $\mathrm{NCl}-\mathrm{UK}$ session had low consumable costs making it $23 \%$ cheaper than usual care.

\section{High cost example}

A 1.5-hour NCl-UK session was run for five residents, but ten staff members and one relative were also present. Music was playing and residents were provided with soft blankets. In addition to tactile objects and soft toys, residents were engaged through hand massages, bringing aspects of nature into the session and playing specific sounds or songs that would be meaningful to individual residents. Drinks were also provided. Although there were many components taking place, none were expensive. However, there was a high number of staff for a relatively small group of residents. It is therefore unsurprising that the $\mathrm{NCl}-\mathrm{UK}$ session was $102 \%$ more expensive than usual care, with the main difference being the high staff costs. For $\mathrm{NCl}-\mathrm{UK}$ the staff costs were over four times those of usual care.

This latter example was an extreme outlier in our data and, when compared with the reality of $\mathrm{NCl}-\mathrm{UK}$ as represented within the qualitative data from the research project, it would seem most likely this arose either due to inappropriate data recording by care staff or because of our assumptive responses to missing data. It is highly unlikely in practice that any care home would have double as many staff in the room as residents, and much more 
likely that other residents, relatives or visitors were included in the 'other people attending' section of the form. The missing data procedures would have exacerbated the error.

Most of the 'extra' cost of $\mathrm{NCl}-\mathrm{UK}$ is a result of the number of staff involved in each session, with staff costs being twice as expensive for $\mathrm{NCl}-\mathrm{UK}$ than for usual care on average. For context, $\mathrm{NCl}$-UK staff costs represent around $30-50 \%$ of the session cost, whereas for a usual care session it is closer to $15-30 \%$. While this is likely to be due in part to the assumptions made around additional people, it is also likely that because $\mathrm{NCl}-\mathrm{UK}$ is a new intervention, more staff were involved than anticipated. Additionally, some sessions involved larger groups of residents than expected, which are more likely to require multiple members of staff. The intention was for a session to be run by one member of staff, but this was the case in $77 \%$ of sessions, and only $65 \%$ of sessions had one member of staff present in total. This is not surprising, as staff may have wanted to work together or observe sessions to learn how to deliver the new intervention, and support each other until they felt more comfortable and able to run a session on their own. This is an important finding because such practical decision-making is likely to arise with the implementation of any new intervention and, as such, the associated costs should be considered as integral to the intervention itself.

As would also be expected for a new intervention, planning time was required prior to the first sessions being delivered. Planning time was more likely to be loaded towards the start of implementation, but as NCI-UK became more established within the care homes and more comfortable for staff to deliver, planning reduced. However, an ongoing low level of planning time was required throughout the delivery period. If a care home chooses to implement $\mathrm{NCl}-\mathrm{UK}$ it should therefore expect an initial start-up period with higher costs relating to session planning and staff learning, before delivery of the intervention becomes embedded within the care home's way of working. 
In addition, it is important to note that the $\mathrm{NCl}-\mathrm{UK}$ costing model and the results stemming from it are based on costing all consumables as 'new' at the start of implementation. In reality, this was not the case for the care homes who obtained consumables via donation or by utilising existing resources in the home. This is discussed in detail in Bray et al. (2019b) but is worth restating as it would suggest that the practical cost of $\mathrm{NCl}-\mathrm{UK}$ for care homes will be lower than reported here. Nonetheless, the findings highlight an important consideration for any new care home intervention and help to explicate costs that can be 'hidden' within practical decision-making and intervention descriptions.

There are different sources of uncertainty within these findings, including the range of $\mathrm{NCl}-$ UK session costs, the range of NSQ outcomes and the fact that the actual impact of usual care is unknown. However, the three scenarios considered within this article as a form of sensitivity analysis using the ICER enable us to interpret our findings. They also provide an indication of the additional costs required to deliver $\mathrm{NCI}-\mathrm{UK}$ in order to see different changes. In a 'best case' scenario for $\mathrm{NCl}-\mathrm{UK}$ where usual care has a detrimental impact on residents, it would be possible to improve NSQ scores by 1 point by spending an extra $£ 1.22$ per resident, per session implementing NCl-UK. Conversely, if usual care already has a positive effect on all residents, spending and extra $£ 4.46$ per resident to provide $\mathrm{NCI}-\mathrm{UK}$ would not offer any comparative benefit in terms of improving NSQ scores. However, experience within the wider research project, and prevailing understandings of care for people living with advanced dementia in care homes, would suggest that usual care is by no means guaranteed to have a positive effect on residents, with the first scenario more often reflected in practice. Therefore $\mathrm{NCI}-U K$ would appear to be a relatively low cost way of improving the lives of people living with advanced dementia in care homes.

Overall, $\mathrm{NCl}-\mathrm{UK}$ was found to have a positive impact on almost every resident involved in the evaluation, but this is achieved at a cost. At a resident level, the average cost per resident, per session was $£ 38.01$, which can be used as a benchmark cost of $\mathrm{NCI}$-UK 
delivery. This equates to an extra $£ 7.24$ per resident, per session compared to usual care. However, as acknowledged, the limitations of the real-world data used within the cost model suggest that this value is higher than the actual cost of $\mathrm{NCl}-\mathrm{UK}$ in practice. While $\mathrm{NCl}-\mathrm{UK}$ costs more than usual care, it was also found to have a positive outcome for most residents, with an average improvement of 1.31 points for the total NSQ score. The decision to implement $\mathrm{NCl}-U K$ within a care home may therefore depend not just on financial factors, but also on a care home's usual care provision.

\section{References}

Bray, J., Atkinson, T., Latham, I. \& Brooker, D. (2019a). Practice of Namaste Care for people living with dementia in the UK, Nursing Older People, Vol. 31 No. 1, pp.22-28.

Bray, J., Brooker, D., Latham, I., Wray, F. \& Baines, D. (2019b). Costing resource use of the Namaste Care Intervention UK: A novel framework for costing dementia care interventions in care homes, International Psychogeriatrics, pp.1-10.

Brooker, D., La Fontaine, J., de Vries, K. \& Latham, I. (2013). The development of PIECEdem: Focussing on the experience of care for people living with advanced dementia, The British Psychological Society Clinical Forum, Vol. 250, pp.38-46.

Simard, J. (2013). Namaste Care: The End of Life Program for People with Dementia, 2nd ed. Health Professions Press, Baltimore.

Latham, I., Brooker, D., Bray, J. Jacobson-Wright, N. \& Frost, F. (2020). Namaste Care Intervention (NCl-UK): The impact of successful implementation in UK care homes for people living with advanced dementia, staff and families, International Journal of Environmental Research and Public Health, Vol. 17, No. 16, p.6004.

Stacpoole, M. \& Thompsell, A. (2014). 'The Namaste Care Programme Benefits and Challenges', available at: https://www.kcl.ac.uk/scwru/events/mbchf/past/2014/stacpooleand-thompsell-10sep14.pdf (accessed 30 October 2020) 
Acknowledgements: We would like to thank all of the care homes who took part in implementing $\mathrm{NCl}-\mathrm{UK}$ and captured valuable NSQ details about the sessions and residents.

Conflict of interest declaration: None 
Table I: Overview of $\mathrm{NCI}-\mathrm{UK}$ sessions delivered

\begin{tabular}{|c|c|c|c|c|c|c|c|}
\hline $\begin{array}{l}\text { Care home } \\
\text { pseudonym }\end{array}$ & $\begin{array}{l}\text { Delivery } \\
\text { period }\end{array}$ & $\begin{array}{c}\text { Total } \\
\text { planning } \\
\text { time } \\
\text { (minutes) }^{*}\end{array}$ & $\begin{array}{l}\text { Number } \\
\text { of } \mathrm{NCl}-\mathrm{UK} \\
\text { sessions }\end{array}$ & $\begin{array}{l}\text { Type of } \\
\text { room }\end{array}$ & $\begin{array}{c}\text { NCI-UK session } \\
\text { duration } \\
\text { (minutes) } \\
\text { mean (range) }\end{array}$ & $\begin{array}{l}\text { No. residents } \\
\text { per session } \\
\text { mean (range) }\end{array}$ & $\begin{array}{l}\text { No. staff running } \\
\text { a session } \\
\text { mean (range) }\end{array}$ \\
\hline $\begin{array}{c}\text { Azalea } \\
\text { Court }\end{array}$ & 6 months & 2940 & 121 & $\begin{array}{c}\text { Space } \\
\text { within care } \\
\text { home }\end{array}$ & 67 (45 to 120$)$ & 8.01 (2 to 18$)$ & 1.27 (1 to 4 ) \\
\hline $\begin{array}{l}\text { Clover } \\
\text { House }\end{array}$ & 3 months & 1800 & 60 & $\begin{array}{c}\text { Space } \\
\text { within care } \\
\text { home }\end{array}$ & 89 (60 to 90$)$ & 9.15 (2 to 18$)$ & $1(1)$ \\
\hline $\begin{array}{c}\text { Elm } \\
\text { Gardens }\end{array}$ & 6 months & 5160 & 144 & $\begin{array}{c}\text { Dedicated } \\
\text { room }\end{array}$ & $92(30$ to 120$)$ & 6.44 (2 to 12$)$ & 1.53 (1 to 3 ) \\
\hline $\begin{array}{l}\text { Foxglove } \\
\text { Place }\end{array}$ & $\begin{array}{c}4.5 \\
\text { months }\end{array}$ & 1440 & 165 & $\begin{array}{l}\text { Dedicated } \\
\text { room }\end{array}$ & 109 (45 to 120$)$ & 4.73 (1 to 12$)$ & $1(1)$ \\
\hline $\begin{array}{c}\text { Gardenia } \\
\text { Lodge }\end{array}$ & $\begin{array}{c}4.5 \\
\text { months }\end{array}$ & 1020 & 31 & $\begin{array}{l}\text { Dedicated } \\
\text { room }\end{array}$ & 118 (90 to 120$)$ & 3.97 (2 to 6 ) & 1.48 (1 to 2 ) \\
\hline Overall & $\begin{array}{l}\text { Up to } 6 \\
\text { months }\end{array}$ & 12360 & 521 & n/a & 93 (30 to 120$)$ & $6(1$ to 18$)$ & 1.24 (1 to 4 ) \\
\hline
\end{tabular}

* including planning during the month prior to delivery 
Table II: Total NCI-UK and usual care session costs

\begin{tabular}{|c|c|c|c|c|c|}
\hline Care home & $\begin{array}{l}\text { Number of } \\
\mathrm{NCl}-U K \\
\text { sessions }\end{array}$ & $\begin{array}{c}\text { Total no. of } \\
\text { attendances } \\
\text { by } \\
\text { residents }\end{array}$ & $\begin{array}{l}\text { Total } \mathrm{NCl}- \\
\text { UK cost }\end{array}$ & $\begin{array}{c}\text { Total usual } \\
\text { care cost }\end{array}$ & $\begin{array}{c}\text { Percentage } \\
\text { additional } \\
\text { cost of } \\
\mathrm{NCl}-\mathrm{UK} \\
\text { compared } \\
\text { to UC }\end{array}$ \\
\hline $\begin{array}{c}\text { Azalea } \\
\text { Court }\end{array}$ & $\begin{array}{c}121 \text { (over } 6 \\
\text { months) }\end{array}$ & 969 & $£ 23,061.06$ & $£ 18,736.67$ & $\begin{array}{l}23 \% \text { higher } \\
\text { for NCl }\end{array}$ \\
\hline $\begin{array}{l}\text { Clover } \\
\text { House }\end{array}$ & $\begin{array}{c}60 \text { (over } 3 \\
\text { months) }\end{array}$ & 549 & $£ 17,469.62$ & $£ 15,396.37$ & $\begin{array}{c}13 \% \text { higher } \\
\text { for NCl }\end{array}$ \\
\hline $\begin{array}{c}\text { Elm } \\
\text { Gardens }\end{array}$ & $\begin{array}{c}144 \text { (over } 6 \\
\text { months) }\end{array}$ & 927 & $£ 31,786.54$ & $£ 25,248.11$ & $\begin{array}{l}26 \% \text { higher } \\
\text { for } \mathrm{NCl}\end{array}$ \\
\hline $\begin{array}{l}\text { Foxglove } \\
\text { Place }\end{array}$ & $\begin{array}{c}165 \text { (over } 4.5 \\
\text { months) }\end{array}$ & 781 & $£ 33,496.59$ & $£ 26,762.81$ & $\begin{array}{l}25 \% \text { higher } \\
\text { for NCl }\end{array}$ \\
\hline $\begin{array}{l}\text { Gardenia } \\
\text { Lodge }\end{array}$ & $\begin{array}{c}31 \text { (over } 4.5 \\
\text { months) }\end{array}$ & 123 & $£ 9,079.92$ & $£ 8,897.25$ & $\begin{array}{l}2 \% \text { higher } \\
\text { for } \mathrm{NCl}\end{array}$ \\
\hline
\end{tabular}


Table III: Average NCI-UK and usual care session costs (in GBP £) by type of resource

\begin{tabular}{|c|c|c|c|c|c|c|c|c|c|c|c|c|}
\hline \multirow[t]{2}{*}{$\begin{array}{l}\text { Care } \\
\text { Home }\end{array}$} & \multicolumn{4}{|c|}{$\begin{array}{c}\mathrm{NCl} \text {-UK session cost }(£) \\
\text { mean(range) }\end{array}$} & \multicolumn{4}{|c|}{$\begin{array}{c}\text { Usual Care session cost }(£) \\
\text { mean(range) }\end{array}$} & \multicolumn{4}{|c|}{$\begin{array}{c}\text { Absolute difference between } \mathrm{NCI}-\mathrm{UK} \text { and usual } \\
\text { care }(£) \\
\text { mean(range) }\end{array}$} \\
\hline & Staff & Capital & Consumables & Total & Staff & Capital & Consumables & Total & Staff & Capital & Consumables & Total \\
\hline $\begin{array}{c}\text { Azalea } \\
\text { Court }\end{array}$ & $\begin{array}{c}95.59 \\
(33.72 \text { to } \\
165.45)\end{array}$ & $\begin{array}{l}23.20 \\
(19.25 \text { to } \\
33.00)\end{array}$ & $\begin{array}{c}71.80(16.22 \text { to } \\
186.37)\end{array}$ & $\begin{array}{c}190.59 \\
(83.34 \text { to } \\
365.00)\end{array}$ & $\begin{array}{c}41.97 \\
(31.21 \text { to } \\
51.89)\end{array}$ & $\begin{array}{c}23.20 \\
(19.25 \text { to } \\
33.00)\end{array}$ & \begin{tabular}{|c}
$89.68(26.64$ to \\
$194.01)$
\end{tabular} & $\begin{array}{c}154.85 \\
(82.49 \text { to } \\
257.32)\end{array}$ & $\begin{array}{l}53.62 \\
(2.51 \text { to } \\
118.85)\end{array}$ & 0 & $\begin{array}{l}-17.88 \\
(-137.13 \text { to } \\
55.12)\end{array}$ & $\begin{array}{c}35.74 \\
(-95.23 \text { to } \\
148.80)\end{array}$ \\
\hline $\begin{array}{l}\text { Clover } \\
\text { House }\end{array}$ & $\begin{array}{c}108.87 \\
(50.41 \text { to } \\
253.75)\end{array}$ & $\begin{array}{l}27.36 \\
(22.00 \text { to } \\
27.50)\end{array}$ & $\begin{array}{c}154.93(60.62 \\
\text { to } 338.63)\end{array}$ & $\begin{array}{c}291.16 \\
(147.86 \text { to } \\
460.94)\end{array}$ & $\begin{array}{c}45.60 \\
(39.14 \text { to } \\
46.60)\end{array}$ & \begin{tabular}{|c|}
27.36 \\
$(22.00$ to \\
$27.50)$
\end{tabular} & $\begin{array}{c}183.65(48.92 \\
\text { to } 349.54)\end{array}$ & $\begin{array}{c}256.61 \\
(115.56 \text { to } \\
423.64)\end{array}$ & $\begin{array}{c}63.27 \\
(11.27 \text { to } \\
207.15)\end{array}$ & 0 & $\begin{array}{c}-28.71 \\
(-135.73 \text { to } \\
44.66)\end{array}$ & $\begin{array}{c}34.55 \\
(-87.52 \text { to } \\
229.71)\end{array}$ \\
\hline $\begin{array}{c}\text { Elm } \\
\text { Gardens }\end{array}$ & $\begin{array}{c}100.71 \\
(45.12 \text { to } \\
159.26)\end{array}$ & $\begin{array}{c}63.57 \\
(37.50 \text { to } \\
75.00)\end{array}$ & $\begin{array}{c}56.47(15.38 \text { to } \\
123.58)\end{array}$ & \begin{tabular}{|c|}
220.74 \\
$(110.50$ to \\
$310.38)$
\end{tabular} & $\begin{array}{c}46.02 \\
(33.85 \text { to } \\
51.89)\end{array}$ & $\begin{array}{c}63.57 \\
(37.50 \text { to } \\
75.00)\end{array}$ & $\begin{array}{c}65.75(24.97 \text { to } \\
116.49)\end{array}$ & $\begin{array}{c}175.33 \\
(108.82 \text { to } \\
243.38)\end{array}$ & $\begin{array}{c}54.69 \\
(11.27 \text { to } \\
110.02)\end{array}$ & 0 & $\begin{array}{c}-9.28 \\
(-46.50 \text { to } \\
35.85)\end{array}$ & $\begin{array}{c}45.41 \\
(-2.85 \text { to } \\
121.79)\end{array}$ \\
\hline $\begin{array}{l}\text { Foxglove } \\
\text { Place }\end{array}$ & $\begin{array}{c}81.63 \\
(33.16 \text { to } \\
138.66)\end{array}$ & $\begin{array}{c}70.25 \\
(43.75 \text { to } \\
75.00)\end{array}$ & \begin{tabular}{|c}
$51.12(8.21$ to \\
$124.21)$
\end{tabular} & \begin{tabular}{|c|}
203.01 \\
$(91.69$ to \\
$299.30)$
\end{tabular} & $\begin{array}{c}45.81 \\
(31.21 \text { to } \\
51.89)\end{array}$ & $\begin{array}{c}70.25 \\
(43.75 \text { to } \\
75.00)\end{array}$ & $\begin{array}{c}45.14(14.40 \text { to } \\
105.16)\end{array}$ & $\begin{array}{c}162.20 \\
(89.36 \text { to } \\
232.04)\end{array}$ & $\begin{array}{c}35.82 \\
(1.95 \text { to } \\
89.42)\end{array}$ & 0 & $\begin{array}{c}5.98 \\
(-33.95 \text { to } \\
43.59)\end{array}$ & $\begin{array}{c}40.80 \\
(-17.07 \text { to } \\
112.23)\end{array}$ \\
\hline $\begin{array}{l}\text { Gardenia } \\
\text { Lodge }\end{array}$ & $\begin{array}{c}78.11 \\
(50.41 \text { to } \\
123.64)\end{array}$ & $\begin{array}{c}74.19 \\
(62.50 \text { to } \\
75.00)\end{array}$ & $\begin{array}{c}140.59(58.41 \\
\text { to } 244.30)\end{array}$ & $\begin{array}{c}292.90 \\
(189.11 \text { to } \\
442.95)\end{array}$ & $\begin{array}{c}46.01 \\
(39.14 \text { to } \\
51.89)\end{array}$ & $\begin{array}{c}74.19 \\
(62.50 \text { to } \\
75.00)\end{array}$ & $\begin{array}{c}166.80(98.78 \\
\text { to } 235.75)\end{array}$ & $\begin{array}{c}287.01 \\
(209.31 \text { to } \\
362.63)\end{array}$ & $\begin{array}{c}32.10 \\
(11.27 \text { to } \\
71.75)\end{array}$ & 0 & $\begin{array}{c}-26.21 \\
(-108.27 \text { to } \\
41.26)\end{array}$ & $\begin{array}{c}5.89 \\
(-65.53 \text { to } \\
113.02)\end{array}$ \\
\hline Overall & $\begin{array}{c}93.07 \\
(33.16 \text { to } \\
253.75)\end{array}$ & $\begin{array}{c}52.77 \\
(19.25 \text { to } \\
75.00)\end{array}$ & \begin{tabular}{|c|}
$74.68(8.21$ to \\
$338.63)$
\end{tabular} & $\begin{array}{c}220.53 \\
(83.34 \text { to } \\
460.94)\end{array}$ & $\begin{array}{c}44.96 \\
(31.21 \text { to } \\
51.89)\end{array}$ & $\begin{array}{c}52.77 \\
(19.25 \text { to } \\
75.00)\end{array}$ & $\begin{array}{c}84.37(14.40 \text { to } \\
349.54)\end{array}$ & $\begin{array}{c}182.42 \\
(82.49 \text { to } \\
423.64)\end{array}$ & $\begin{array}{c}48.11 \\
(1.95 \text { to } \\
207.15)\end{array}$ & 0 & $\begin{array}{c}-9.69 \\
(-137.13 \text { to } \\
55.12)\end{array}$ & $\begin{array}{c}38.10 \\
(-95.23 \text { to } \\
229.71)\end{array}$ \\
\hline
\end{tabular}


Table IV: Overview of NSQ cases, NCI-UK and comparable usual care costs (in GBP $£$ ), and NSQ changes

\begin{tabular}{|c|c|c|c|c|c|c|c|c|c|}
\hline \multirow{2}{*}{$\begin{array}{l}\text { Care } \\
\text { home }\end{array}$} & \multirow{2}{*}{$\begin{array}{l}\text { Number of } \\
\text { participating } \\
\text { residents }\end{array}$} & \multirow{2}{*}{$\begin{array}{c}\text { Number of } \\
\text { NSQ } \\
\text { resident } \\
\text { cases }\end{array}$} & \multicolumn{2}{|c|}{$\begin{array}{l}\text { Costs per resident }(£) \\
\text { Mean (range) }\end{array}$} & \multirow{2}{*}{$\begin{array}{c}\text { Incremental } \\
\text { NCl-UK cost } \\
\text { per resident (£) } \\
\text { Mean (range) }\end{array}$} & \multicolumn{4}{|c|}{$\begin{array}{l}\text { Actual NSQ change for residents in NCI-UK sessions } \\
\text { Mean (range) }\end{array}$} \\
\hline & & & NCI-UK & $\begin{array}{l}\text { Usual } \\
\text { care }\end{array}$ & & $\begin{array}{l}\text { Physical } \\
\text { wellbeing }\end{array}$ & $\begin{array}{l}\text { Emotional } \\
\text { wellbeing }\end{array}$ & $\begin{array}{l}\text { Alertness/ } \\
\text { awareness }\end{array}$ & Total \\
\hline $\begin{array}{l}\text { Azalea } \\
\text { Court }\end{array}$ & 7 & 348 & $\begin{array}{l}24.75 \\
(9.01 \text { to } \\
41.67)\end{array}$ & $\begin{array}{c}19.89 \\
(14.30 \text { to } \\
41.25)\end{array}$ & $\begin{array}{c}4.86(-5.29 \text { to } \\
11.45)\end{array}$ & 0.77 (-2 to 3$)$ & 1.21 (-1 to 4$)$ & $1.03(-1$ to 3$)$ & $\begin{array}{c}3.01(-1 \text { to } \\
9)\end{array}$ \\
\hline $\begin{array}{l}\text { Clover } \\
\text { House }\end{array}$ & 7 & 165 & $\begin{array}{c}38.73 \\
(18.67 \text { to } \\
90.4)\end{array}$ & $\begin{array}{l}29.99 \\
(23.54 \text { to } \\
45.05)\end{array}$ & $\begin{array}{c}8.73(-5.58 \text { to } \\
45.35)\end{array}$ & $\begin{array}{l}-0.12(-4 \text { to } \\
4)\end{array}$ & $1.16(-4$ to 4$)$ & $0(-4$ to 4$)$ & $\begin{array}{c}1.43(-12 \text { to } \\
11)\end{array}$ \\
\hline $\begin{array}{c}\text { Elm } \\
\text { Gardens }\end{array}$ & 13 & 439 & $\begin{array}{l}35.08 \\
(23.37 \text { to } \\
74.12)\end{array}$ & $\begin{array}{l}27.52 \\
(19.09 \text { to } \\
63.31)\end{array}$ & $\begin{array}{c}7.56(-3.33 \text { to } \\
24.36)\end{array}$ & 0.05 (-2 to 3$)$ & $0.35(-2$ to 3$)$ & $0(-3$ to 3$)$ & $\begin{array}{c}0.54(-7 \text { to } \\
7)\end{array}$ \\
\hline $\begin{array}{l}\text { Foxglove } \\
\text { Place }\end{array}$ & 14 & 620 & $\begin{array}{c}43.07 \\
(19.02 \text { to } \\
128.25)\end{array}$ & $\begin{array}{l}34.27 \\
(19.34 \text { to } \\
116.04)\end{array}$ & $\begin{array}{c}8.80(-6.11 \text { to } \\
17.48)\end{array}$ & 0.23 (-2 to 2$)$ & 0.31 (-3 to 2$)$ & $0.29(-3$ to 4$)$ & $\begin{array}{c}0.83(-8 \text { to } \\
6)\end{array}$ \\
\hline $\begin{array}{c}\text { Gardenia } \\
\text { Lodge }\end{array}$ & 7 & 77 & $\begin{array}{c}72.48 \\
(53.05 \text { to } \\
113.70)\end{array}$ & $\begin{array}{c}72.03 \\
(60.44 \text { to } \\
109.10)\end{array}$ & $\begin{array}{c}0.45(-16.38 \text { to } \\
22.60)\end{array}$ & 0.43 (0 to 4$)$ & $0.64(-2$ to 3$)$ & 0.51 (-1 to 3$)$ & $\begin{array}{c}1.57 \text { (-1 to } \\
9)\end{array}$ \\
\hline Overall & 48 & 1649 & $\begin{array}{l}38.01 \\
(9.01 \text { to } \\
128.25)\end{array}$ & $\begin{array}{l}30.77 \\
(14.30 \text { to } \\
116.04)\end{array}$ & $\begin{array}{c}7.24(-16.38 \text { to } \\
45.35)\end{array}$ & $\begin{array}{c}0.27(-4 \text { to } \\
4)\end{array}$ & 0.61 (-4 to 4$)$ & $0.43(-4$ to 4$)$ & $\begin{array}{c}1.31(-12 \text { to } \\
11)\end{array}$ \\
\hline
\end{tabular}




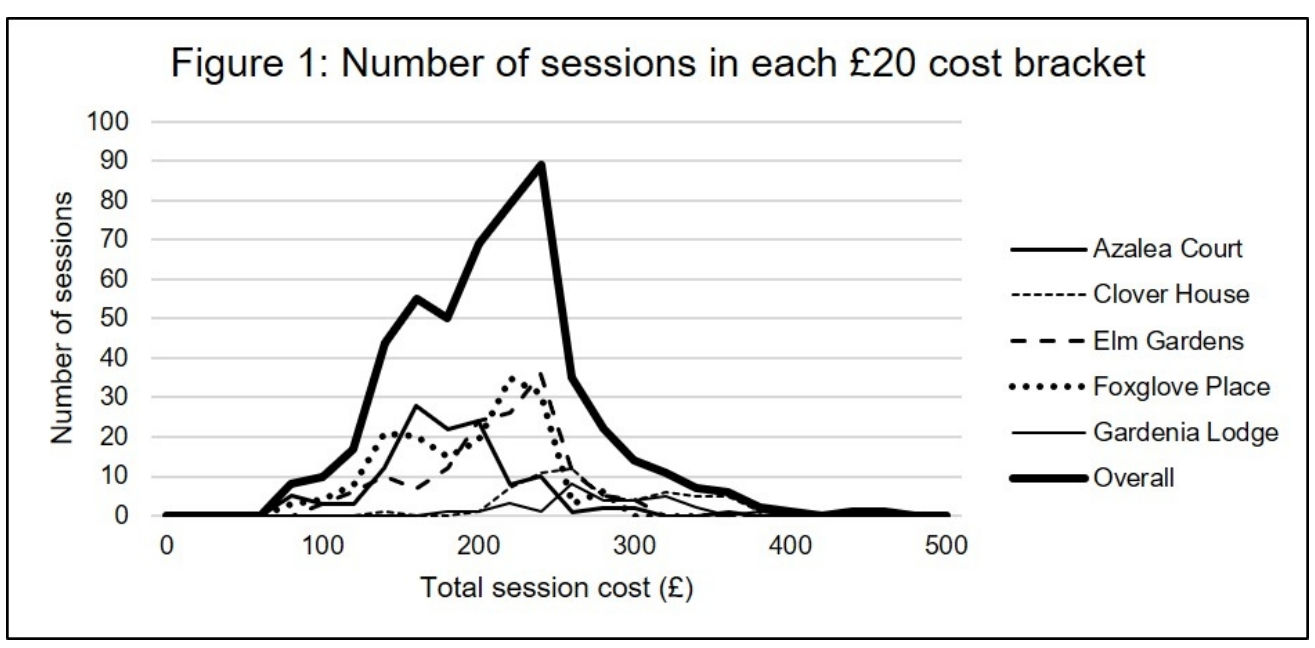

Figure 1: Number of sessions in each $£ 20$ cost bracket $159 \times 76 \mathrm{~mm}(150 \times 150 \mathrm{DPI})$ 